\title{
CATOLICISMO CARISMÁTICO BRASILEIRO EM PORTUGAL
}

\author{
Eduardo Gabriel
}

Resumo: A expansão religiosa a partir de países do Sul em direção aos países do Norte, a que se chama o retorno missionário, é um fenômeno que tem sido bastante discutido em trabalhos que abordam a temática dos fluxos de mobilidade religiosa transnacionais. O presente artigo pretende contribuir para este debate através do estudo da expansão do catolicismo carismático brasileiro com a chegada a Portugal da comunidade Canção Nova, traçando algumas pistas para a análise das tensóes entre o catolicismo português e o catolicismo brasileiro.

Palavras-Chave: mobilidade religiosa; Renovação Carismática Católica; catolicismo

Abstract: Religious expansion from the Southern to the Northern countries, which is called the missionary reflux (or reverse flow), is a phenomenon which has been much discussed in work on transnational religious mobility. This article is a contribution to this debate: it examines the expansion of charismatic Brazilian catholicism with the arrival in Portugal of the Canção Nova community, providing some guidelines for analyzing the tensions between Portuguese catholicism and Brazilian catholicism.

Keywords: Religious mobility; Charismatic Catholic Renewal; catholicism.

\section{INTRODUÇÃO}

A expansão internacional do catolicismo carismático brasileiro com investidas na fixação em países especialmente europeus é um fenômeno refratário de um contexto mais amplo, em que a expansão religiosa em todo o mundo segue a passos largos um fluxo migratório dos países do Sul em direção aos países do Norte. Esse momento corresponde ao que alguns investigadores têm designado como "retorno missionário" das ex-colônias para as suas ex-metrópoles.

${ }^{1}$ Doutor pela Universidade de São Paulo - Bolsista Fundação de Amparo à Pesquisa do Estado de São Paulo.

Debates do NER, Porto Alegre, ano io, N. I6, P. 95-II9, Jul./Dez. 2009 
O presente texto tratará de apontar algumas pistas iniciais sobre este fenômeno, tomando como exemplo a expansão da comunidade brasileira Canção Nova, particularmente com a sua instalação missionária em Portugal. Assim, como trataremos de argumentar, a missão religiosa e histórica da Canção Nova em Portugal parece seguir num único sentido, que é o de reavivar a memória católica da catequização empreendida séculos atrás em direção ao que foi chamado Novo Mundo. De uma conversão indígena em massa à Santa Madre Igreja ocorrida no século XVI, o sopro do espírito católico renovado brasileiro no final do século XX inflama o ideário missionário da Canção Nova a converter os católicos portugueses para dentro da própria Igreja Católica, tendência esta bastante característica do movimento de Renovação Carismática Católica, como foi já apontado por vários estudos, que realçam a capacidade de este movimento católico trazer de volta os fiéis católicos afastados ou que mantinham uma relação distante com a Igreja (Benedetti, 1988, 2006; Camurça, 2001; Carranza, 2000, 2005, 2006; Gabriel, 2005; Mariz, 1999, 2000, 2003, 2004, 2006; Prandi, 1998). Trataremos aqui de esboçar estes ecos de um "anti-projecto" religioso recolonizador de sentido inverso, que tem como ferramentas não as quinquilharias (que eram oferecidas ao "bom selvagem" para a aproximação), mas o que há de mais próprio aos tempos atuais, ou seja, o uso dos meios de comunicação.

Nos encontros de oração da Canção Nova em Portugal podem-se ouvir pregaçóes que manifestam fervorosamente o desejo que os missionários brasileiros têm de difundir o "verdadeiro" batismo no Espírito Santo, como é chamado no movimento de Renovação Carismática Católica (RCC), o que esboça um projeto missionário afinado aos tempos de modernidade, no qual é dada especial ênfase à "experiência" subjetiva na construção de uma renovada identidade religiosa, cuja orientação é o próprio sujeito da experiência quem dá. De um ritual de sacramento institucional, o batismo católico tradicional, que funcionava como um ritual de incorporação do indivíduo no conjunto das relaçóes sociais e na comunidade religiosa, e que era quase sempre realizado por vontade familiar, temos agora uma nova proposta de batismo, que se baseia na opção individual do sujeito já adulto, e que passa

Debates do NER, Porto Alegre, ano io, N. I6, P. 95-II9, Jul./Dez. 2009 
pela sua própria experimentação de uma relação de proximidade com a divindade. $\mathrm{O}$ batismo no Espírito dependerá apenas de um êxtase coletivo imanente no desempenho performático do ritual religioso, com muitos cânticos e gesticulação corporal propiciadores deste novo batismo, do qual o indivíduo sairá verdadeiramente renovado. A confirmação deste batismo no Espírito Santo é feita após este momento coletivo, quando o dirigente do grupo de oração pergunta publicamente quem está se sentindo melhor e renovado. Uns e outros dão testemunhos daquilo que lhes aconteceu, ou seja, de como estavam antes e como se sentem a partir desta experiência, além do que esperam mudar doravante em suas vidas. Assim, a dinâmica deste novo batismo requer um acontecimento público e coletivo. Ninguém diz ter recebido o batismo no Espírito Santo estando sozinho.

A análise que se seguirá neste texto terá justamente esta intenção de descrever o processo da chegada da Canção Nova a Portugal, o qual trouxe na bagagem este "novo batismo" aos portugueses católicos, que de quebra também tem particularidades brasileiras. Considerado, no início, um fenômeno estranho, ao longo destes últimos dez anos os missionários brasileiros procuraram encontrar similitudes para a incorporação cultural e profética da sua presença em Portugal junto de um dos mais prestigiados santuários marianos católicos do mundo, o santuário de Nossa Senhora de Fátima. Um exemplo disto pode ser detectado num discurso do padre fundador $\mathrm{da}$ Canção Nova, Jonas Abib, quando afirma que:

Também nós, cá no Brasil, nos privilegiamos com as mensagens de Fátima, pois Nossa Senhora falou aos pastorinhos na nossa língua comum. (Jonas Abib, 2007)

Para a finalidade da proposta de um batismo experimentado subjectivamente, e que é deslocado das funçôes somente do processo ritual, os usos da linguagem tornam-se componentes centrais na dinâmica religiosa de intento individualizante. Ao contrário da Igreja Universal do Reino de Deus (IURD), comunidade evangélica brasileira que teve, em Portugal, vários problemas de relacionamento com as tradições e costumes do país,

Debates do NER, Porto Alegre, ano io, N. I6, P. 95-II9, Jul./Dez. 2009 
e foi até alvo de muita contestação (Mafra, 2002), a Canção Nova tentou aprofundar os aspectos que a poderiam tornar mais próxima das tradiçóes portuguesas, em particular aquelas que tinham a ver com a respeitada aura das apariçóes de Fátima. Ao afirmar que Nossa Senhora falou numa língua comum a portugueses e brasileiros, Abib não deixa de evidenciar que há uma grande diferença entre a língua portuguesa falada pelos portugueses, e a língua portuguesa falada pelos brasileiros, e que esta diferença não reside apenas numa simples variação de pronuncias, mas também nas culturas, como será apontado adiante. Assim, durante as pregaçôes, os missionários brasileiros procuram adaptar alguns dos seus jargões às expressōes utilizadas pelos portugueses. Isso parece resolver como pensam os missionários brasileiros, o problema da diferença cultural e de linguagem entre brasileiros e portugueses.

\section{PROJEÇÕES BRASILEIRAS DA IMAGEM EXPANSIONISTA}

No dia 7 de Setembro de 2007, a Rede Globo de televisão exibiu um programa chamado "Redescobrindo Portugal". Na exata data da comemoração civil da independência brasileira, esta empresa de comunicação divulga um documentário emblemático sobre a relação entre o Brasil e Portugal. Vale a pena deter-mo-nos em algumas passagens deste documentário, pois servir-nos-á para elucidar a análise sobre a missão da Canção Nova em Portugal. Comecemos por pensar sobre o porquê da apresentação de um programa sobre Portugal no dia da independência do Brasil.

O objetivo do programa era desvendar as terras e a cultura de Portugal e mostrar aos brasileiros aspectos "inéditos" deste país. O primeiro bloco do documentário era composto por cenas historicamente nada estranhas. As imagens encadeadas faziam uma releitura contemporânea dos descobrimentos do século XVI, como se mostrou na abertura do programa, através da chegada marítima da própria repórter que fazia a apresentação do documentário. Nos blocos seguintes, abordaram-se seqüencialmente os aspectos naturais, da cultura e da sociabilidade portuguesa e, por fim, no

Debates do NER, Porto Alegre, ano io, N. I6, P. 95-II9, Jul./Dez. 2009 
último bloco do programa, tratou-se da presença dos brasileiros em Portugal. Como desfecho dramático, o programa termina com um senhor português olhando ao longe o oceano Atlântico, como se quisesse ver o próprio Brasil. Não é forçoso considerar que, em termos ideológicos, o programa pretende questionar em que medida a nova geração, neste caso os brasileiros imigrantes, caberá dar continuidade às tradiçôes portuguesas?

Parece-nos que a missão da Canção Nova em Portugal se tem mostrado, nas suas atividades religiosas, muito próxima deste ideário histórico de um certo "redescobrimento" religioso de Portugal. Um exemplo pôde ser visto nos dias 16 e 17 de Agosto de 2008, quando a Canção Nova organizou uma grande cerimônia para as comemoraçôes dos seus dez anos de missão em Portugal. O "Hossana Portugal" realizado no auditório Paulo VI, pertencente à administração do Santuário de Fátima, teve como cenário um conjunto de imagens desta primeira década em Portugal representado por três barcos em miniatura, uma bóia salva-vidas, remos e uma rede de pesca. Ao redor da bóia salva-vidas, lia-se a seguinte frase: "Não dá mais para voltar -CN". No começo da cerimônia, um animador da Canção Nova iniciou a apresentação fazendo referência ao episódio histórico da primeira missa rezada no Brasil ter sido celebrada por um padre português e disse:

Hoje a Canção Nova vem retribuir ao povo português esta graça que nós brasileiros recebemos de sermos católicos.

No final do evento, na missa rezada pelo fundador da Canção Nova, uma criança entrega nas mãos do padre Jonas Abib um dos barcos em miniatura que estavam no palco. Seguidamente ele ergue o barco em miniatura como se fosse um troféu de conquista. É preciso dizer que a cerimônia foi transmitida para todo o país pela TV Canção Nova, propriedade desta comunidade.

A imagem que parece ser projetada nestes dois episódios, por um lado no programa da Rede Globo, e por outro nas comemoraçóes dos 10 anos da Canção Nova em Portugal, embora com estilos diferentes, expressa um desejo manifesto de uma atuação que se espera ser desempenhada pelos brasileiros em Portugal. Como interpretação sociológica trataremos de

Debates do NER, Porto Alegre, ano io, N. I6, P. 95-II9, Jul./Dez. 2009 
verificar as tensões nas relações sociais e de poder que este projeto envolve ao longo do seu desenvolvimento, e de que forma o estilo do catolicismo carismático brasileiro se relaciona com o catolicismo português.

Assim, trataremos de elaborar um quadro de oposiçóes entre o modelo de catolicismo carismático brasileiro, centrado numa dinâmica performática, em que a figura do leigo ganha destaque e o laço hierárquico é frouxo, e o catolicismo português, essencialmente tradicionalista, caracterizado por uma forte ênfase devocional no ritual litúrgico, e um contexto em que o movimento carismático português tem pouca penetração eclesiástica na hierarquia e entre os fiéis.

\section{INÍCIO DA RENOVAÇÃO CARISMÁTICA CATÓLICA}

Para compreender melhor a dinâmica religiosa da qual o catolicismo carismático brasileiro faz parte, e assim contextualizar as tensóes decorrentes do seu processo de expansão, em particular no caso da chegada da Canção Nova a Portugal, é preciso recordar brevemente o processo geral de surgimento do movimento de Renovação Carismática Católica (RCC) e o seu desenvolvimento no Brasil, elencando os seus principais episódios históricos. A reconstrução deste trajeto é fundamental para entender os elementos propiciadores da expansão internacional do catolicismo carismático brasileiro, além de suas conseqüências.

A RCC tem suas origens no marco das experiências espirituais do chamado "Fim de Semana de Duquesne", ocorrido entre 17 e 19 de Fevereiro de 1967. Nesta ocasião, vinte e cinco jovens universitários reuniram-se no centro de retiros "The ark and the dove", situado na região de North Hills, Pittsburgo, Pennsylvânia, nos Estados Unidos, para orar e estudar a Bíblia. A partir deste encontro, que teve como tema os Atos dos Apóstolos, o catolicismo começa a conhecer uma nova dinâmica espiritual, caracterizada pela presença do "Espírito Santo", um dos três elementos da Santíssima trindade católica - "Pai", "Filho" e "Espírito Santo".

Debates do NER, Porto Alegre, ANo io, N. I6, P. 95-II9, JUl./DeZ. 2009 
O próprio movimento carismático, ao contar a sua história, relata este acontecimento da seguinte maneira:

Reunidos, então, na capela de North Hill, dia 18 de Fevereiro de 1967, Sábado, começaram a orar, cantar e a pedir a vinda renovada do Espírito Santo em suas vidas. Durante as cinco horas em que estiveram prostrados diante do sacrário, alguns jovens sentiram sua fé transformar-se de intelectual para praticante.

Vicente Borragán Mata retrata esta experiência da seguinte maneira:

Uns sentiram que o amor de Deus por eles era tão intenso, que não podiam senão chorar; outros sentiam um imenso calor a passar, como fogo, pelos seus braços e mãos; outros sentiam ruídos na garganta e formigueiros na língua, outros falam de louvores gozosos que saíam dos seus lábios, de um encontro pessoal com Jesus como Senhor, de júbilo e alegria intensa, da presença do Espírito como um fogo devorador, de ânsias de oração e de ler a Palavras de Deus (1999, p. 44).

Esta experiência originária de Duquesne é reproduzida nos dias de hoje nas comunidades católicas de dinâmica carismática em todo o mundo. Este momento é considerado pelos católicos carismáticos como o "batismo no Espírito Santo". Com uma trajetória de quarenta anos, o movimento carismático tem logrado importantes espaços e simpatia no interior da Igreja, ao contrário do que alguns teólogos e intelectuais católicos haviam admitido há algum tempo atrás.

Carranza (2000), no seu estudo sobre este movimento, aponta que existem aproximadamente 40 milhôes de adeptos da RCC no mundo, 270 mil grupos de oração espalhados em 140 países, sendo que $30 \%$ se encontram na América Latina. Esta autora identifica a chegada da RCC ao Brasil em 1969 através dos padres jesuítas Harold Rahm e Eduardo Dougherty, tendo como núcleo a cidade de Campinas/São Paulo. Numa revisão bibliográfica dos estudos sobre a RCC, Cecília Mariz sintetiza:

Debates do NER, Porto Alegre, ano io, N. I6, P. 95-II9, JUl./Dez. 2009 
Embora tenha tido muito sucesso desde a sua criação, o período de maior crescimento do MRCC deu-se na segunda metade da década de 1990. Nesta época, ganha também uma grande visibilidade nos meios de comunicação social, tanto por criar os seus próprios canais de rádio e TV, com programas religiosos, quanto por constituírem notícia: grandes eventos de massas em espaços públicos (2004, p. 172).

As análises que Carranza (2000) faz da trajetória da RCC no Brasil destacam a sua presença significativa ao longo dos anos 70 , seguida de uma consolidação institucional que acompanha a sua difusão por todo território nacional nos anos 80, e que nos anos 90 avança também para o território dos meios de comunicaçáo, passando a deter um lugar nos media. O momento seguinte desta trajetória, como queremos propor neste estudo, é a expansão internacional da RCC brasileira para outros países, fato que começa a ser desencadeado a partir do ano 2000. É preciso assinalar que este itinerário de crescimento da RCC brasileira obedece a lógicas particulares e bastante consolidadas no cenário do catolicismo nacional, gerando com isto significativas e variadas disputas de forças no campo religioso brasileiro. As primeiras são as disputas dentro da própria Igreja Católica. Alvo das divergências clericais, a RCC avança ganhando adeptos na grande massa de fiéis católicos, ao mesmo tempo em que é olhada com desconfiança por parte da hierarquia eclesiástica, dos teólogos e dos intelectuais católicos. Do contingente católico brasileiro, Prandi (1998) aponta que são quase "14\% de católicos cujos parâmetros são os dos movimentos como CEB, RCC, Equipes de Nossa Senhora, etc, que implica a idéia de conversão, de reorientação religiosa" (1998, p. 14).

A base da RCC são os "grupos de oração" (Prandi, 1998). Estes grupos "podem ser interpretados como espaços religiosos que permitem ao fiel procurar uma 'satisfação espiritual', desligando-se do mundo material" (Carranza, 2000, p. 50). Este aspecto da Renovação Carismática tem sido o principal ponto que gera um enfrentamento de oposição ao catolicismo de engajamento social e luta política das Comunidades Eclesiais de Base (CEB), orientadas pela teologia da libertação, que foi a principal bandeira da chamada ala progressista da Igreja Católica.

Debates do NER, Porto Alegre, ano io, N. I6, P. 95-II9, Jul./Dez. 2009 
Uma característica importante da RCC é que ela "tem se mostrado como um movimento leigo e independente em relação à estrutura da Igreja” (Prandi, 1998, p. 52). Mas, algumas reflexōes eclesiásticas sobre a RCC sublinham que "deve ficar claro que para encontrar a sabedoria e a direção necessárias para cumprir sua missão no mundo, os grupos de oração e seus líderes devem manter estreita comunhão com a Igreja e seus pastores designados", como afirmou Dom Paul Josef Cordes (1999, p. 74).

Oliveira, numa das suas primeiras análises, sugeriu simplesmente que "a RCC pode ser definida como um movimento de oração. Suas reuniōes são reuniōes de oração; as pessoas se encontram para orar, dando especial ênfase à oração e louvor" (1978, p. 20). Em 1994 a Conferência Nacional dos Bispos do Brasil (CNBB) publicou um documento a respeito da RCC intitulado Orientaçôes Pastorais sobre a Renovação Carismática Católica. Neste documento são explicitadas orientações pastorais para os carismáticos como: "dê-se especial importância à formação bíblica, que ofereça sólidos princípios de interpretação (...), não se introduzam elementos estranhos à tradição da Igreja (...), evite-se alimentar um clima de exaltação da emoção e do sentimento, que enfatiza apenas a dimensão subjetiva da experiência da fé (...), não se incentive a chamada oração em línguas (...), evite a prática do assim chamado repouso no espírito (...), quanto ao poder do mal, não se exagere a sua importância" (CNBB, 1994). Para Mariz, "essas e outras recomendaçôes de cunho similar tendem a limitar práticas mágicas, vistas como fetichistas que significariam um maior contato do leigo com o sobrenatural" (2004, p. 178). O notável esforço da CNBB é tentar manter o seu controle institucional sobre os meios de culto e pastoral. Mas é inegável uma postura religiosa de caráter destemido do católico carismático, pois "os participantes dos grupos de oração procuram e encontram uma resposta religiosa a suas afliçóes cotidianas, reelaborando sua maneira de ver e agir na sociedade" (Carranza, 2000, p. 51). Orientar-se moral e eticamente de forma destemida por uma identidade religiosa no Brasil contemporâneo requer, por parte do fiel carismático, uma relação de confronto pessoal através do seu comportamento de convicção e como testemunha da ação do Espírito Santo na sua vida, face a um campo religioso plural e dinâmico, e a um

Debates do NER, Porto Alegre, ano io, N. I6, P. 95-II9, JUl./Dez. 2009 
contexto laico quase "demoníaco", como alguns o imaginam, dominado pelo aborto, homossexualismo, drogas, prostituição, separações, etc.

É preciso observar que os dados do censo de 2000 indicaram que a população que se declarava católica correspondia a $73,8 \%$ da população brasileira, enquanto em 1991 esse valor era de 83,3\%, o que significa uma diminuição de $9,5 \%$. A população que se declarava evangélica em 2000 era de $15,5 \%$ da população brasileira, e em 1991 rondava os $9,1 \%$, o que evidencia, portanto, um pertinente e já notável crescimento. No que diz respeito aos "sem-religião", a porcentagem registrada em 2000 era de 7,0\% , enquanto em 1991 esse valor correspondia a apenas 4,8\%. É no âmbito deste contexto religioso de perda da hegemonia da Igreja Católica, que a RCC tem tentado ser, no Brasil, um elemento de contenção desta paulatina evasão de fiéis. Se lembrarmos os dados dos censos de 1970 e 1980, em que respectivamente $91,8 \%$ e $89 \%$ da população brasileira se declarava católica, acentua-se ainda mais este aspecto de contenção que a RCC parece proporse exercer. Para Carranza, a RCC no Brasil "é o único movimento religioso da Igreja Católica que consegue aglutinar, através de eventos massivos, suas camadas populares" (2000, p. 50).

Algumas explicaçôes, como a de Antoniazzi, indicam que "a diminuição da porcentagem de católicos está associada ao rápido crescimento populacional (migraçôes) e à lentidão ou insuficiência da resposta pastoral da própria Igreja a esse fenômeno demográfico" (2004, p. 402). Na mesma direção, Prandi aponta que o catolicismo de modo geral "foi ficando cada vez mais desinteressado de oferecer orientação para a vida quotidiana, sofrendo profundo esvaziamento axiológico" (1998, p. 22).

Num sentido geral, o cenário religioso contemporâneo apresenta-se na condição em que "as formas de experimentar o sagrado passam por outros caminhos que não são, necessariamente, os institucionais, marcados pela tradição, pelo zelo doutrinal, pelas exigências éticas de transformação do mundo" (Carranza, 2005a, p. 61).

Se Peter Berger sentencia que "a religião serve para manter a realidade daquele mundo socialmente construído no qual os homens existem nas suas vidas cotidianas" (1985, p. 55), a RCC não pode deixar de levar em conta

Debates do NER, Porto Alegre, ano io, N. I6, P. 95-II9, Jul./Dez. 2009 
no interior da sua dinâmica espiritual esta configuração religiosa brasileira que citamos acima. Em sentido mais amplo, estamos diante de um cenário religioso em que "ao olharmos para o século XXI encontramos uma realidade muito contraditória", ou seja, "uma situação que admite todos os medos e todas as esperanças" (Houtart, 2002, p. 17). Este conteúdo é coincidentemente um dos aspectos mais reforçados nos contornos devocionais do Santuário de Fátima, em Portugal, possível de todas as aproximações, como se frisará neste estudo.

Por fim, se "o problema fundamental das instituições religiosas é como sobreviver num meio que já não considera evidentes as suas definições de realidade" (Berger, 1985, p. 163), a RCC vem conquistando um espaço de visibilidade religiosa ancorado nos meios de comunicação social, especialmente centrada numa devoção à Virgem Maria, elemento que confere universalidade e status hegemônico às comunidades carismáticas, como nos interessa investigar a partir desta pesquisa.

\section{CATOLICISMO CARISMÁTICO E OS MEIOS DE COMUNICAÇÃO: O EXEMPLO DA CANÇÃO NOVA}

Como já foi apontado no início do artigo, se o projeto religioso deste "retorno missionário" traz como forma de evangelização o recurso aos meios de comunicação, cabe aqui fazer um balanço de como é que este fenômeno se desenvolveu no contexto brasileiro, observando, para tal, as análises que já foram produzidas.

A presença da Renovação Carismática Católica nos meios de comunicação social é atualmente uma das mais importantes fontes de difusão da evangelização carismática no contexto brasileiro. Carranza (2000) e Mariz (2004), como foi já referido, apontam a década de 90 como o momento em que a RCC passou a ocupar um espaço significativo nos media brasileiros. Segundo Mariz, a partir desse momento "com o desenvolvimento da televisão por assinatura no Brasil, surgem então os canais católicos: a Rede Vida de Televisão, a TV Canção Nova e, posteriormente, a TV Século XXI.

Debates do NER, Porto Alegre, ano io, N. I6, P. 95-II9, JUl./Dez. 2009 
A presença carismática na TV é forte, desses três canais, dois são liderados por padres carismáticos" (2004, p. 177). Analisando a Rede Vida e a RCC (TV Canção Nova e TV Século XXI), Carranza afirma que "ambos têm um público alvo, o católico; ambos têm uma carga moralizante, catequética, doutrinária e litúrgica nos seus programas; ambos se reconhecem como o braço leigo da Igreja nas estruturas do mundo e ambos assumem sua presença na mídia como uma missão evangelizadora” (2000, p. 280). Por sua vez, a respeito das atividades da Igreja Católica com os canais televisivos, Ralph Della Cava e Paula Montero (1991) identificam que é a partir da transmissão da missa dominical em emissoras leigas que a Igreja experiência os primeiros contatos com a estrutura televisiva.

A partir desta observação, os autores ressaltam que a transmissão da missa dominical exemplifica "um dos casos emblemáticos que resume de forma cristalina o embate ideológico que se trava no interior da instituição em torno da recorrente pergunta: quem são os grupos legítimos que poderão dar a interpretação 'correta' sobre o papel da Igreja na sociedade de hoje?" (1991, p. 222). Esta incipiente experiência na transmissão da missa dominical através da televisão produz uma reação de preocupação na hierarquia da Igreja, pois "a transmissão da missa, que no início era realizada quase como um prolongamento da celebração no templo, ao sabor das iniciativas locais, se torna um 'novo' rito, cujo formato, sentido e estatuto é preciso definir" (1991, p. 222). Tais preocupaçóes estiveram na origem dos encontros regionais e nacionais sobre a liturgia na rádio e na televisão, promovidos nos anos 70 pelo setor "Liturgia e Meios de Comunicação" da CNBB.

A emissora carismática TV Canção Nova (TVCN) detém hoje uma significativa presença nos meios de comunicação social. Uma das principais apresentaçóes da TVCN são os acampamentos de oração $0^{2}$ : "Tudo o que acontece no acampamento é transmitido ao vivo, tanto pela rádio da $\mathrm{CN}$ como pelo sistema televisivo (TVCN). Dessa forma as pessoas que assistem aos acampamentos são simultaneamente participantes e auditório dos pro-

${ }^{2}$ Os fiéis permanecem dois ou três dias acampadas em tendas, utilizam banheiros comuns e comem em barracas improvisadas (Carranza, 2000, p.67).

Debates do NER, Porto Alegre, ano io, N. I6, P. 95-II9, Jul./Dez. 2009 
gramas" (Carranza, 2000, p. 67). Esta emissora foi inaugurada no dia 8 de Dezembro de 1989. Atualmente a Canção Nova comporta um sistema de comunicação com custos em torno de $\mathrm{R} \$ 11$ milhôes mensais, quantia que extravasa em muito um nível tipicamente paroquiano.

\section{SANTUÁRIO DE FÁTIMA - PORTUGAL E O FENÔMENO DAS APARIÇÓES MARIANAS}

É preciso explicitar algumas informações sobre o Santuário de Fátima (Portugal), local estrategicamente escolhido para a formação da grande base de difusão da Canção Nova a partir do exterior. Afastando-nos de qualquer prognóstico religioso que associe a escolha deste local a uma inspiração divina, como é invocado pelos membros da Cançáo Nova ao afirmarem a existência de um "chamado de Deus ao coração do Padre Jonas", é possível antes afirmar, como sugere Mariz, que "Fátima seria a aparição por definição do século XX" (2000, p. 6).

Num detalhado registro sobre as aparições de Fátima organizado por Augusto Dias Arnaut e Gabriel Ferreira Marques (1953, 1954 e 1955) torna-se patente o grande status dado a este fenômeno religioso. Estes autores reúnem em três compêndios os principais aspectos sobre o desdobramento e o percurso da mensagem de Fátima, analisando os motivos que justificam que este local das apariçóes se tenha tornado um "altar do mundo".

Se a chegada da Canção Nova a Fátima pode ser inicialmente vista como uma aproximação pela simples via da devoção ao culto mariano (traço característico da Renovação Carismática, como foi já apontado), é possível depreender que Fátima também oferece à Canção Nova outros atrativos, nomeadamente uma certa dinâmica de "difusão" internacional.

Assim, é plausível a hipótese de que uma das estratégias a que a Canção Nova recorreu na sua expansão para fora do Brasil, e de modo particular com a sua chegada a Portugal, tenha passado pela instalação em Fátima, local de "visibilidade" e "difusão" mundial como pólo católico de peregrinação e devoção. A ambivalência que isto pode acarretar deve ser pensada por um

Debates do NER, Porto Alegre, ano io, N. I6, P. 95-II9, Jul./Dez. 2009 
lado em termos da disputa de forças que tal fenômeno gera no interior do campo religioso brasileiro, e por outro lado em termos da consolidação da legitimidade nas manifestações carismáticas do catolicismo brasileiro perante a Santa Sé.

No seu estudo sobre as apariçōes marianas, Mariz (2000) procura discutir a forma como a Igreja Católica lida com essas aparições e as tensóes que ocasionam, reunindo importantes elementos teóricos para analisar esta devoção católica. Para Mariz, "as apariçōes são muitas vezes interpretadas como um aviso da Mãe de Deus para evitar o desvio da Igreja e dos costumes por ela defendidos" (2000, p. 8). As mensagens das aparições ganham importante peso na Renovação Carismática, movimento em que os costumes tradicionais do catolicismo (reza do terço, novenas, penitência, devoção aos santos, fidelidade à Igreja, etc.) têm constituído uma importante marca da atual fé carismática.

Analisando as aparições de Taquari, município do Rio Grande do Sul, Steil (2001) interessa-se por observar a presença dos carismáticos nesta aparição. Este autor afirma que

em Taquari, como em muitos contextos de apariçóes, diferentemente de outros momentos históricos, o clero não se apresenta mais como única alternativa de mediação entre uma 'tradição local' de caráter popular e a 'tradição universal', de uma religiáo que transcende os contextos locais (...), o que é novo em relação às apariçōes marianas hoje é que há uma alternativa à mediação do clero, representada pelos carismáticos, que sáo capazes de retirar o evento do seu contexto geográfico e local e inscrevê-lo numa cultura globalizada, dando-lhe repercussão e visibilidade (2001, p. 144-145).

Seguindo a sugestáo analítica proposta por Steil, torna-se evidente o caráter mediador que a RCC assume em fenômenos relacionados com a devoção mariana, sobretudo quando observamos as informaçóes sobre Nossa Senhora de Fátima disponível na página da internet da Canção Nova. Neste site, o católico carismático tem a oportunidade de ficar informado sobre todas as atividades eclesiais (missas, procissões, peregrinaçóes, novena) relacionadas com a devoção a Fátima. Não se trata de uma página

Debates do NER, Porto Alegre, ano io, N. I6, P. 95-II9, Jul./Dez. 2009 
exclusivamente dedicada a informações sobre Fátima, mas um local em que as notícias e informes estão acessíveis através de um link - Especial Nossa Senhora de Fátima -, entre outros diferentes links disponíveis para informaçōes católicas.

É preciso sublinhar que as informações a respeito de Fátima se encontram quase em exclusivo no portal ${ }^{3} \mathrm{da}$ Canção Nova e que, pelo que pudemos observar, as páginas dos outros movimentos da Renovação Carismática Católica não dispóem de tais informações.

O que nos parece estar em causa é, conforme propóe Nathan Mitchell, que "a internet muda não apenas o como nós 'acessamos a informação', mas muda a própria natureza do como nós lemos” (2005, p. 98).

Manter a devoção mariana a Nossa Senhora de Fátima pelo acesso exclusivo aos meios de comunicação da Canção Nova coloca a natureza dessa devoção em condições particulares em volta de uma submissão dogmática ainda mais acentuada, embora acrescida do prestígio e visibilidade internacional que o Santuário de Fátima oferece.

\section{TENSŌES COM A CHEGADA DA CANÇÃO NOVA A PORTUGAL}

Face ao contexto enunciado acima relativo ao aparecimento de um movimento católico com aspectos pentecostais, a RCC, aos usos dos meios de comunicação para evangelização e ao significado envolvido nas apariçôes de Fátima, coloca-se a questão de como conjugar então este catolicismo carismático brasileiro expansivo e performático, como tem sido desde as suas origens, com as tensóes e os desarranjos simbólicos que desencadeia no campo católico convencional e na dinâmica do campo católico português, no qual a difusão da sua mensagem passa, em grande medida, pela TV Canção Nova e pela Rádio Canção Nova. Um exemplo da importância destes media

\footnotetext{
${ }^{3}$ Segundo informações da própria homepage : "O Portal Canção Nova - www.cancaonova. com, que conta actualmente com mais de 1.500.000 acessos mensais, tem levado através da Internet a "Palavra de Deus" a todas as pessoas do mundo".
}

Debates do NER, Porto Alegre, ano io, N. 16, P. 95-II9, JUl./DeZ. 2009 
pôde ser observado numa conversa entre duas senhoras na rodoviária de Fátima, em que uma delas dizia: "eu tenho em casa a TV Canção Nova, e gosto muito de assistir; há sempre programas religiosos e as missas... assisto sempre".

Como análise desta conjugação, é preciso evocar aqui a importante teorização da sociologia da religião de Max Weber (2006). Será nas tensóes com as ações de forças intramundanas de caráter a-racional ou anti-racional que Weber identifica as principais formas de relação das tensōes religiosas, "sobretudo, tratando-se das esferas estética e erótica" (2006, p. 337). Assim, elementos como "a música utilizada como meio auxiliar do êxtase" (...) "cantores e dançarinos sacros" (...) "as escalas dos sons" (...) "o passo de dança" (...) "templos e igrejas, por serem as maiores de todas as construçôes" (...) "paramentos e apetrechos litúrgicos de todo o tipo"(...) "tudo isto fez, desde sempre, da religião uma fonte inesgotável de possibilidades de desenvolvimento artístico, por um lado, e de estilização do compromisso com a tradição, por outro lado". Com isto, começa a ficar sociologicamente compreensível o motivo pelo qual a senhora portuguesa diz gostar de assistir à TV Canção Nova, que apesar de refletir um catolicismo carismático imbuído de traços de brasilianismo, lhe oferece em simultâneo o acesso direto à sua tradição: as missas.

Não por acaso, as mais fortes e visíveis reações por parte de algumas lideranças religiosas portuguesas contra a presença desta comunidade brasileira em Portugal foram desencadeadas por ocasião do processo de instalação da TV Canção Nova no país. Para interpretarmos o fenômeno da recepção da Canção Nova em Portugal tomaremos como referencial teórico-metodológico os estudos de Norbert Elias (2000), com seu modelo explicativo da figuração "estabelecidos-outsiders", elaborado a partir da análise das relaçóes entre dois diferentes grupos sociais numa mesma pequena comunidade. $\mathrm{O}$ efeito desta relação, como analisado por Elias, e que mais nos interessa reter aqui é o processo de estigmatização pelo qual certo grupo se vê impelido como ação socialmente construída por parte do outro grupo, tendo como diferencial dinamizador a condição do tempo de permanência naquela pequena comunidade. A aplicação deste modelo

Debates do NER, Porto Alegre, ano io, N. I6, P. 95-II9, JUl./Dez. 2009 
metodológico torna-se possível neste estudo por haver encadeado todos os componentes de figuração para uma estigmatização da Canção Nova e o efeito de uma disputa de poderes em torno de Fátima.

No dia 5 de Julho de 2001, no jornal Público, o jornalista Antonio Marújo, publicou um artigo com o título: "Canal católico brasileiro perde apoio de um dos parceiros portugueses". A Ajuda à Igreja que Sofre, uma instituição missionária católica presente em todo o mundo e muito respeitada pela hierarquia da Igreja, iria apoiar a instalação da TV Canção Nova em Portugal, mas, por alguma razão de força maior, retirou o seu apoio ao projeto. $\mathrm{O}$ artigo de Marújo refere que

A AIS advoga duas razões para se afastar do projecto: 'dúvidas' sobre a total sintonia da Comunidade Canção Nova (CCN) com a hierarquia católica brasileira, e discordância com o que considera uma 'mentalidade, jansenista, intolerante, moralista e intimista', com pouca preocupação 'pela justiça no mundo e pouca sintonia com a doutrina social da Igreja', que estarão na orientação do canal.

Para rebater estas críticas, o responsável e administrador da Canção Nova em Portugal, que é português, teria afirmado, segundo o artigo de Marújo, que:

As críticas (...) são 'inverdadeiras' e que provêm de alguém ligado a uma Igreja de teólogos e não à Igreja de apóstolos, de que fazem parte os membros da comunidade Canção Nova.

Neste artigo, que segue como uma ilustração cabal deste processo de tensóes de poder a tentativa de estigmatização da Canção Nova, é patentemente um processo que se quis começar a construir. Num outro artigo de 18 de Outubro de 2001, o mesmo jornalista apresenta a posição do episcopado português ao dizer que a iniciativa da TV Canção Nova em Portugal é exclusiva da comunidade Canção Nova, e que não esta não teria o apoio da conferência episcopal. Vale a pena lembrar que o grande apoio

Debates do NER, Porto Alegre, ANo io, N. I6, P. 95-II9, JUl./Dez. 2009 
que esta comunidade recebeu, e que permitiu o seu estabelecimento em Portugal, partiu do bispo Dom Serafim, da diocese de Leiria-Fátima, hoje bispo emérito, e que parece ter tido sempre a capacidade de fazer valer as suas decisóes políticas de pastor, dada a inequívoca importância que esta diocese possui por nela se situar o santuário de Fátima, sob sua jurisdição religiosa na ocasião da instalação dos missionários brasileiros em Portugal. No meio de tantas críticas à permanência da Canção Nova em Portugal, um documento redigido por lideranças leigas, e que teve o apoio de vários bispos, colocou em causa a continuação dos missionários brasileiros em solo português. Esta foi a mais emblemática reação de um grupo de católicos portugueses sobre o início da TVCN em Portugal. Este documento não logrou êxito como meio para impedir o avanço da Canção Nova em Portugal. Conseqüentemente, a permanência é um fator político muito importante das relações com os fiéis portugueses que os missionários brasileiros passam a ter ao seu favor.

Todo este contexto enredado de críticas e "dúvidas" sobre a instalação da TV Canção Nova em Portugal nos remete para uma situação de "ataque tríplice" pela qual passam muitos grupos estabelecidos: "contra seu monopólio das fontes de poder, contra seu carisma coletivo e contra suas normas grupais" (Elias, 2000, p. 50).

Se a fixação de um grupo "outsider" requer um empenho na melhoria das condiçôes de aproximação com o grupo "estabelecido", como aponta Elias, o esforço imediato da Canção Nova foi procurar estas condiçóes possíveis de aproximação, o que justifica as declarações do padre Jonas Abib, em 2007, quando das comemoraçóes dos nove anos da comunidade Canção Nova em Portugal: "Também nós, cá no Brasil, nos privilegiamos com as mensagens de Fátima, pois Nossa Senhora falou aos Pastorinhos na nossa língua comum. Não se pode, porém, negar que foi ao povo da vossa nação que Ela falou em primeiro lugar. O privilégio é vosso".

Esta declaração do padre Jonas Abib, que não é aleatória ou simplesmente comemorativa, traduz muito do que Norbert Elias aponta nas reflexões da sua teoria simbólica, quando ao pensar sobre os fluxos de linguagem, aponta que "a capacidade de controlar os padrões de conhecimento e da fala

Debates do NER, Porto Alegre, ano io, N. I6, P. 95-II9, JUl./Dez. 2009 
numa sociedade é, geralmente, um aspecto concomitante da distribuição das oportunidades de poder numa sociedade" (2002, p. 8).

Assim, tem sido sob o pálio destas oportunidades de poder que as investidas dos batismos no Espírito Santo parecem ocorrer nos encontros de evangelização do catolicismo carismático que os missionários brasileiros têm promovido em Portugal.

Se os entraves colocados à implementação da TV Canção Nova exigiram por parte da comunidade o dispêndio de um grande esforço institucional no sentido de provarem a sua idoneidade religiosa e fixarem o seu projeto de evangelização em Portugal, isso só parece ter sido possível devido à clareza do projeto religioso carismático brasileiro, que procura encontrar cada vez mais o seu lugar no campo católico português através de um duplo movimento: por um lado distanciando-se da tradição religiosa portuguesa secular, que não pertence à história da Canção Nova, mas que por ela deve ser creditada; por outro, produzindo esforços contra-ofensivos que reforçam a sua identidade como movimento católico carismático brasileiro, distinto e oposto a outras igrejas brasileiras como a "Igreja do Reino de Deus", por exemplo, que pretende submergir a tradição cultural e religiosa de Portugal.

Desta forma, o projeto de religiosidade carismática brasileira a ser propalado nos encontros de louvor da Canção Nova diz respeito a uma idéia de um novo "jeito de ser" e que sugere com isso que as pessoas possam ter "um novo mundo ao seu alcance". Os termos "jeito de ser" e "um novo mundo ao seu alcance", fazem parte de um sofisticado e bem trabalhado slogan de marketing religioso que a comunidade Canção Nova tem divulgado, e que aqui podemos identificar como ferramentas estratégicas utilizadas na disputa pelo poder, a fim de assegurar o seu lugar no campo religioso e combater a falta de aceitação de que tem sido alvo. $\mathrm{O}$ uso do marketing é por sinal uma característica bastante distintiva do catolicismo carismático, já apontado em muitos estudos sobre as comunidades carismáticas, mas cujo papel no desenvolvimento religioso tem sido até agora pouco discutido.

A conjunção destes dois slogans tem produzido uma outra idéia bastante emblemática, sob o lema "Ser Canção Nova é bom DEMAIS". Este slogan teve a sua origem nos encontros da Canção Nova ocorridos na sua

Debates do NER, Porto Alegre, ano io, N. I6, P. 95-II9, JUl./Dez. 2009 
sede, na cidade Cachoeira Paulista, interior de São Paulo, e já se começa a manifestar paulatinamente em Portugal como produto da sua presença no país ao longo da última década.

A partir da articulação destes três elementos, o aspecto religioso manifestado no batismo no Espírito caminha como uma necessidade de consumo que perpassa os pólos de uma origem distintiva (catolicismo brasileiro), a proposta de uma condição distinguível entre o que já há até então disponível (novo mundo) e a garantia de satisfação na sua aquisição (bom demais).

Resta agora, portanto, observar como esta performance e tensão estão sendo assimiladas na dinâmica religiosa católica portuguesa e incidem sobre os fiéis que já se aproximaram da Canção Nova e a quem cabe a tarefa de divulgar a marca e os produtos da Canção Nova. Parece que o batismo no Espírito Santo de aproximação entre o catolicismo carismático brasileiro e o catolicismo português se tem ocupado em elaborar uma "oração no espírito" que possa conseguir enfrentar as tensóes no controle da sexualidade, ou seja, na esfera erótica, que Weber considera a mais concorrencial com a religião, como já referimos (2006, p. 339).

Nos encontros da Canção Nova realizados na Cachoeira Paulista, não é raro ouvirem-se expressōes de louvor e oraçōes em defesa da castidade, do controle da sexualidade, do namoro santo e da virgindade. As orientaçóes sobre estes temas partem do próprio fundador, o padre Jonas Abib, cujas reflexões são em parte consultáveis no site da Canção Nova ${ }^{4}$. Outros líderes da comunidade, como o Prof. Felipe Aquino, tem tido também um papel de destaque nas orientaçóes da comunidade sobre este tema ${ }^{5}$.

No primeiro texto do Padre Jonas que citamos - "Nossa sexualidade não pode ser profanada", a preocupação parece voltar-se para a questão

\footnotetext{
${ }^{4}$ Disponível em: <http://www.cancaonova.com.br> V. "Nossa sexualidade não pode ser profanada!", publicado no dia 26 de Junho de 2008 e "Nossa sexualidade é sagrada!", publicado no dia 7 de Julho de 2008.

${ }^{5}$ V. "Sexo no plano de Deus", publicado na home page da Canção Nova no dia 4 de Julho de 2008, ou "Como viver a castidade no mundo erotizado", publicado na home page da Canção Nova de Portugal no mesmo ano, além de outras tantas investidas em debates nos seus programas apresentados na TV Canção Nova no Brasil.
}

Debates do NER, Porto Alegre, ano io, N. I6, P. 95-II9, Jul./Dez. 2009 
exclusiva da dimensão do matrimônio. "A paternidade e a maternidade são coisas sagradas e santas", afirma o padre Jonas. "Por isso não pode haver infidelidade nem adultério entre o casal. Não pode haver profanação do matrimônio em Deus". Procurando perceber em que medida esta idéia dogmática da centralidade do matrimônio pode ter eco entre os portugueses, encontramos uma importante pista no texto de José Machado Pais (2001), que analisa as dezesseis dimensóes que podem explicar a religiosidade dos portugueses, em especial na seção dedicada à dimensão da "sexualidade e da vida familiar".

Dos 43\% dos chamados "católicos ritualistas, moralistas e tradicionais" (Pais, 2001, p. 195), 77\% pensam que as relaçōes sexuais antes do casamento são sempre erradas, $76 \%$ não concordam com a idéia de "viver junto antes de casar", $80 \%$ discordam da idéia de que "não faz mal viver junto sem casar", 90\% acham que as relações homossexuais são sempre erradas e $88 \%$ acham erradas as relaçóes sexuais fora do casamento. Estes dados apontam-nos que a ênfase para este grupo de católicos é posta na idéia do casamento como sacramento institucionalizado pela Igreja Católica. Assim, "para os católicos ritualistas, moralistas e tradicionais, a religião funciona como um capote sagrado, que cobre as representaçóes que se têm sobre a vida e que permitem encará-la com uma ilusória segurança ontológica" (Pais, 2001, p. 208). Este parece-nos ser também o porto seguro onde o catolicismo carismático em geral, e o brasileiro em particular, se estabelece como sedimentação doutrinária, mas neste caso não tanto como uma mera forma ilusória, mas antes performática, como comportamento a ser seguido. Nas comemoraçóes dos dez anos da Canção Nova em Portugal, um dos momentos fortes da cerimônia foram os depoimentos de portugueses que tiveram contato com a Canção Nova e que testemunharam o que mudou na sua vida a partir dessa experiência. $\mathrm{O}$ depoimento mais emblemático foi o de um casal português da cidade do Porto, cujo matrimônio se restabeleceu a partir das pregaçóes e missas a que assistiram na TV Canção Nova. Por sua vez, a filha do casal conseguiu tirar o seu namorado dos cultos da Igreja Universal do Reino de Deus e o outro filho tomou a decisão de ingressar na Canção Nova para ser missionário. Esta família portuguesa recebeu o novo

Debates do NER, Porto Alegre, ano io, N. I6, P. 95-II9, Jul./Dez. 2009 
batismo que a Canção Nova trouxe a Portugal, que passou necessariamente por momentos de transformação em vários níveis.

Podem-se observar ainda outras manifestações deste novo batismo no Espírito Santo. Todos os encontros de oração carismática começam com um abraço ao irmão que está atrás, o aperto de mão a quem está na frente, um sorriso à pessoa que está ao lado, atos estes que servem para que cada um perceba a presença do outro ao seu lado e seja também percebido, e que devem necessariamente preceder a vinda do Espírito Santo. "O que você quer entregar ao Senhor esta noite? Medo que meu casamento acabe, medo que meus filhos me abandonem, medo da velhice", diz a pregadora que vai conduzindo a cerimônia e os ensinamentos carismáticos como se fosse o pensamento de cada um. "Meu irmão, minha irmã, você que se sente fraco, que se sente esgotado, que se sente só por ter sido abandonado pelos seus familiares, seus amigos, pede o Espírito Santo, vem Espírito Santo me transformar", diz a pregadora ao grupo de oração em Lisboa. Após a oração em diversas línguas, outra missionária relatou a sua experiência durante o momento de cura em que estava possuída pelo Espírito Santo. Disse ela: "Jesus vai curando a prostituição em você que está aqui hoje, eu sinto muito forte isso".

A cura da prostituição só pode acontecer com uma figuração anterior, em que a pessoa é remetida para as suas dificuldades do quotidiano. É por isso que a pregadora insiste: "é preciso pedir o Espírito Santo todos os dias". Assim, a preocupação da Canção Nova em Portugal é com esta via de dois sentidos entre o quotidiano e o extra- quotidiano sublimado, em que transitam concorrencialmente o "Espírito Santo" e a "prostituição", podendo esta ser vista como uma metáfora que traduz a condição dos que estão debilitados, fragilizados, abandonados ou esgotados, condiçôes que propiciam uma dinâmica religiosa performática, pessoal e intimista, oposta a uma dinâmica mais hieraquizada, de cariz ritualista e impessoal, como é a do catolicismo português. Esta parece-nos ser a diferença essencial e aquela que expressa de forma mais objetiva as tensões entre o catolicismo brasileiro e o catolicismo português.

Para terminar, é preciso dirigirmos de novo o olhar para o espaço

Debates do NER, Porto Alegre, ano io, N. I6, P. 95-II9, Jul./Dez. 2009 
onde o catolicismo brasileiro se instalou em Portugal. O estabelecimento da Canção Nova em Portugal deu-se num local conhecido como "UMA REGIÃO COM ALMA!” (Região Turística de Leiria/Fátima), espaço onde se situa o santuário de Fátima. Pensando no significado da escolha desta região, não podemos deixar de considerar que a instalação da Canção Nova no epicentro simbólico do catolicismo português poderá ter funcionado como uma forma de projetar e difundir dentro de Portugal, e para todo o mundo, modelos e práticas com os quais o catolicismo brasileiro mantém uma relação geracional: o catolicismo brasileiro, recentemente instalado nesta regiāo, fornece agora um retorno expansionista àquilo que um dia o catolicismo português gerou. Este equilíbrio, que resulta de uma tensão pela disputa de poder entre a tradição e uma nova modalidade de desempenho do religioso, como o caso aqui exemplificado neste estudo demonstra, é a condição que a expansão internacional do catolicismo carismático brasileiro parece experimentar.

\section{REFERÊNCIAS BIBLIOGRÁFICAS}

ARNAUT, A. D. e Marques, G. F. Fátima Altar do Mundo: o Culto de Nossa Senhora em Portugal. Porto: Ocidental, 1953, Vol.1.

ARNAUT, A. D. e Marques, G. F. Fátima Altar do Mundo: História das Apariçóes. Porto: Ocidental, 1954, Vol.2.

ARNAUT, A. D. e Marques, G. F. Fátima Altar do Mundo: A Imagem Peregrina. Porto: Ocidental, 1955, Vol. 3.

BENEDETTI, L. R. Templo, Praça, Coração: A Articulação do Campo Religioso Católico. Tese (Doutorado)-Faculdade de Filosofia Letra e Ciências Humana, Universidade de São Paulo, São Paulo, 1988

BENEDETTI, L. R. (2006). Religiāo: trânsito ou indiferenciação? In: TEIXEIRA, F. e MENEZES, R. (orgs.). As Religiōes no Brasil. Continuidades e Rupturas. Petrópolis: Vozes, 2006. p. 123-133.

BERGER, P. L. O Dossel Sagrado: Elementos Para Uma Teoria Sociológica da Religião. São Paulo: Paulinas, 1985.

Debates do NER, Porto Alegre, ano io, N. I6, P. 95-II9, JUl./DeZ. 2009 
CAMURÇA, M. A. Renovação carismática católica: entre tradição e a modernidade. Rhema, vol. 7, n. 25, p.45-56, 2001.

CARRANZA, B. Renovação Carismática Católica: Origens, Mudanças e Tendências. Aparecida: Editora Santuário, 2000.

CARRANZA, B. Movimentos do catolicismo brasileiro: cultura, mídia, instituição. Tese (doutorado)-IFCH/Unicamp, Campinas, 2005a.

CARRANZA, B. Lógicas e desafios do contexto religioso contemporâneo. Revista Eclesiástica Brasileira. Vol .LXV, n. ${ }^{\circ} 257$, p.46-63, 2005 b.

CARRANZA, B. Catolicismo midiático. In: TEIXEIRA, F. e MENEZES, R. (orgs.). As Religióes no Brasil. Continuidades e Rupturas. Petrópolis: Vozes, 2006. pp. 69-87.

CONFERÊNCIA NACIONAL DOS BISPOS DO BRASIL (CNBB). Orientações Pastorais sobre a Renovação Carismática Católica. Documentos $C N B B-53,4{ }^{\mathrm{a}}$ ed., São Paulo, Paulinas, 2001 [1994].

CORDES, P. J. Reflexóes sobre a Renovação Carismática Católica. São Paulo: Loyola, 1999.

DELLA CAVA, R. \& MONTERO, P. E o Verbo se Faz Imagem: Igreja Católica e os Meios de Comunicação no Brasil - 1962-1989. Petrópolis: Vozes, 1991.

ELIAS, N. Teoria Simbólica. Oeiras: Celta Editora, 2002.

ELIAS, N. e SCOTSON, J. Os Estabelecidos e os Outsiders. Rio de Janeiro: Jorge Zahar Editor, 2000.

GABRIEL, E. A Evangelização Carismática Católica na Universidade: o Sonho do Grupo de Oração Universitário. Dissertação (Mestrado)-Programa de Pósgraduação em Ciências Sociais, Universidade de Federal de São Carlos, 2005.

HOUTART, F. Mercado e Religiāo. São Paulo: Cortez, 2002.

MAFRA, Clara. Na posse da palavra. Religião, Conversão e Liberdade Pessoal em dois contextos nacionais. Lisboa: Imprensa de Ciências Sociais, 2002.

MARIZ, C. L. "A teologia da batalha espiritual: uma revisão da bibliografia”. $B I B$, vol. 47, p.33-48, 1999.

Debates do NER, Porto Alegre, ano io, N. I6, P. 95-II9, Jul./Dez. 2009 
MARIZ, C. L. Apariçóes da Virgem e o fim do milênio. ANPOCS, 2000. Mimeo.

MARIZ, C. L. Comparando a Rede TV com a Vinde TV. In.: BIRMAN, Patrícia. Religiāo e espaço público. São Paulo: Attar, 2003.

MARIZ, C. L. A Renovação Carismática Católica no Brasil: uma revisão da bibliografia. In: RODRIGUES, Donizete (org.). Em nome de Deus: a religião na sociedade contemporânea. Porto: Ediçôes Afrontamento, 2004. p.169-183.

MARIZ, C. L. Catolicismo no Brasil contemporâneo: reavivamento e diversidade. In: TEIXEIRA, Faustino e MENEZES, Renata (orgs). As religiōes no Brasil. Continuidades e rupturas. Petrópolis: Vozes, 2006.

MATA, V. B. Como um vendaval: o Renovamento Carismático. Lisboa: Pneuma, 1999.

MITCHELL, N. D. Ritual e Nova Mídia. Concilium, 309, p.95-105, 2005.

OLIVEIRA, P. A. R. Renovação Carismática Católica - uma Análise Sociológica: Interpretaçôes Teológicas. Petrópolis: Vozes, 1978.

PAIS, J. M. O que explica a religiosidade dos portugueses? Um ensaio de análise tipológica. In: PAIS, J.M. et al. Atitudes Sociais dos Portugueses. Religiáo e Bioética. Lisboa: Imprensa de Ciências Sociais, 2001. p.185-235.

PRANDI, R. Um sopro do Espírito. São Paulo: Editora da Universidade de São Paulo-Fapesp, 1995.

STEIL, C. A. Apariçōes marianas contemporâneas e carismatismo católico. In: SANCHIS, P. (org.), Fiéis \& Cidadãos. Percursos do Sincretismo no Brasil. Rio de Janeiro: Ed. UERJ, 2001. p. 117-146.

WEBER, M. Sociologia das Religiōes e Consideraçôes Intermediárias. Lisboa: Relógio d'Água Editores, 2006.

Debates do NER, Porto Alegre, ANo io, N. I6, P. 95-II9, JUl./Dez. 2009 
